\title{
原著論文
}

\author{
超小型コードレス筋電困計測システムの \\ 夜間睡眠時咬筋筋活動測定への応用
三上紗季 $^{1)}$, 山口泰彦 ${ }^{1,2)}$, 岡田和樹 ${ }^{2)}$, 後藤田章人 ${ }^{2)}$, 松田慎平 ${ }^{1)}$
1) 北海道大学大学院歯学研究科顎機能医療学講座顎咬合学教室
2) 北海道大学病院高次口腔医療センター \\ 〔受付：平成21年 1 月 19 日]
}

\section{Application of the ultraminiature cordless electromyogram measurement system to assessment of masseteric activity during nocturnal sleep}

\author{
Saki Mikami ${ }^{1)}$, Taihiko Yamaguchi ${ }^{1,2)}$, Kazuki Okada $^{2)}$, Akihito Gotouda $^{2)}$, Shinpei Matsuda ${ }^{1)}$ \\ ${ }^{1)}$ Dept. of Gnatho-occlusal Function, Graduate School of Dental Medicine, Hokkaido University \\ ${ }^{2)}$ Dept. of Temporomandibular Disorders, Center for Advanced Oral Medicine, Hokkaido University Hospital \\ [Received: January 19, 2009]
}

Keywords: sleep bruxism, masseter muscle, electromyography, cordless, telemeter

\begin{abstract}
Purpose: To establish a simple and reliable method for assessment of sleep bruxism (SB) in clinical dentistry, we have developed an ultraminiature cordless electromyogram system, BMS. We have examined the validity of the BMS in an awake state in the daytime and the influence of motion of simulated sleep-turning and scratching motion on the device. In the present study, as a preliminary step to practical application of the device to SB assessment, we examined whether EMG activities could be properly recorded without significant trouble by using the BMS in an actual home sleep environment.

Methods: The subjects were nine bruxers and nine non-bruxers. EMG activities of the masseter muscle during sleep were measured by using the BMS for two days in the subjects' homes. The data obtained during the second night were analyzed and compared between the two groups. EMG bursts with amplitude of $20 \%$ of maximum voluntary contraction (MVC) or more and with duration of $0.25 \mathrm{~s}$ or more were selected. Start and end of the sleep period were detected by using an actigraph. (AMI Ltd.)

Results: All subjects could set up and operate the BMS by themselves. The EMG bursts obtained by using the BMS during sleep could be properly recognized and analyzed. Artifact signals with a linear-spike shape, which were thought to be radio wave communication errors, were occasionally observed, but the signals could be distinguished from actual muscle activities and were eliminated. The number of bursts, burst time and integration of bursts per hour of sleep period of bruxers were significantly larger than those of non-bruxers, and the mean values in bruxers were 6.3-times, 3.2-times and 2.5-times larger, respectively, than those in non-bruxers. The duration per burst of bruxers
\end{abstract}

連絡先：干060-8586 札幌市北区北13条西 7 丁目

TEL: 011-706-4856 FAX: 011-706-4856 
was significantly smaller than that of non-bruxers. There was no significant difference between the two groups in the average of RMS values of burst and sleep time.

Conclusion: It was confirmed that masseteric EMG burst during sleep in the home environment could be properly recognized and analyzed both in bruxers and non-bruxers in BMS measurement. The BMS is thought to have capacity for practical use as a monitoring device of masseteric activity during sleep.

抄録 目的：歯科臨床における簡便で精度の高い睡眠時ブラキシズム（SB）の評価法の実現を目指し， 我々はこれまで超小型コードレス筋電図計測システム, BMS 開発し, 日中覚醒時の顎運動における測 定精度や夜間睡眠時を想定した体動や装置への接触の影響の検討等を行ってきた. 本研究ではBMSの SB 評価装置としての実用化を図るため, 実際に自宅における夜間睡眠時の咀嚼筋の活動を支障なく測定 できるかどうかの検証を行った。

方法：対象はブラキサー群 9 名, 非ブラキサー群 9 名で, 被験者の自宅にて 2 日間, 右咬筋を対象に測 定を行った． 2 日目のデータを解析の対象とし，最大咬みしめの $20 \%$ 以上大きさで，0.25秒以上持続す るバーストを抽出し，両被験者間で比較した。 入眠と起床の確認には，小型睡眠センサー，アクティグラ フ $(\mathrm{A} \cdot \mathrm{M} \cdot \mathrm{I}$ 社製) を用いた。

結果：すべての被験者で, 自宅での装置の設定, 操作が可能であり，記録されたデータでは筋活動波形 の認識, 解析が可能であった. 稀に混入した通信エラーと考えられるスパイク状のノイズは, データ解析 時に識別，除去が可能であった，ブラキサー群と非ブラキサー群の筋活動の比較では, 睡眠 1 時間あたり のバースト数, バースト時間, バースト積分值において, ブラキサー群は非ブラキサー群と比較して有意 に大きな值を示し,それぞれ前者は後者の6.3倍，3.2倍，2.5倍だった．バースト毎の持続時間の平均值は， ブラキサー群は非ブラキサー群と比較して有意に小さな值を示した.バースト RMS 值, 睡眠時間につい ては両群間で有意差は認められなかった。

結論：BMS を用いた測定では，ブラキサー群と非ブラキサー群の自宅における夜間睡眠時の咬筋筋活 動波形の認識, 解析が可能なことが示され, BMS は睡眠時の臨床的な咬筋筋活動モニターとして実用可 能な装置と考えられた。

キーワード 睡眠時ブラキシズム，咬筋，筋電図，コードレス，無線テレメーター

\section{I．緒言}

睡眠時ブラキシズム（SB）は, 顎関節症 ${ }^{1,2)}$ や，歯周 組織破壊 ${ }^{3)}$, 歯の咬耗 ${ }^{4)}$, 破折 ${ }^{5)}$, 歯冠修復物の脱離 ${ }^{6)}$ 等 の多くの歯科疾患の原因としての関与が疑われており， 歯科臨床において SB の評価法の重要性は広く認識され ている.

睡眠時咀嚼筋筋活動モニターは比較的客観性のあ る SB の評価法として期待されている，中でも，筋 電図ほかの生体信号を記録する睡眠ポリグラフ検査 (polysomnograph ; PSG) ${ }^{7-12)}$ と音声記録, ビデオ撮影 を組み合わせた検査法 (audio-video polysomnographic recording, 以下 PSG-AV) ${ }^{8)}$ は, 今のところ, SB 診断の ゴールドスタンダードとされている.しかし, PSG-AV
は, 必要な装備の関係で, 通常, 睡眠実験室での宿泊検 査が必要となり, 費用が高額となることや被験者の負担 が大きいことから連夜の測定や多くの被験者の測定が困 難である。また，慣れない環境での実験室効果の問題も 指摘されている ${ }^{13)}$. 記録項目を筋電図に限定した携帯型 筋電計は, 被験者の自宅での測定が可能であり, これま でもそのような携帯型筋電計を用いた睡眠時の咀嚼筋筋 活動モニターに関する報告は行われている ${ }^{14-22)}$. しかし， 電極のコードが枕元あるいは体幹に設置した記憶装置ま で繋がっているものが多く，違和感が強いとともに，体 動によるノイズの影響が大きい等の問題があり, 臨床で 一般的に使用されるには至っていない, そのため, 臨床 の現場では, 現在も問診や歯の咬耗, 粘膜の圧痕等で判 断されているのが現状である. 最近では, 小型軽量で使 い捨ての歯ぎしりセンサーが開発されており ${ }^{23)}$, 簡便さ 
の点では非常に優れてはいるが，一定閥値以上の筋活動 の頻度を 4 段階に表示するのみで，筋電図原波形の解析 はできないため筋活動の強度や実時間の把握は困難であ る.

我々は，上記のような諸問題を踏まえ，臨床の場で一 般的に応用できるような, より簡便で精度の高いブラキ シズムの評価法の実現を目指し，原田電子工業株式会社 と共同で，電極，増幅アンプを一体化した無拘束の超小 型コードレス筋電図計測システム, BMS を開発した ${ }^{24)}$. これまで, BMS の測定精度の検証として, 日中覚醒時 の顎運動における測定精度や, 測定可能な送信ユニット 一受信ユニット間距離の検討，また，夜間睡眠時を想定 した体動や装置への接触の影響の検討を行ってきた。そ の結果, BMS は, 覚醒時の筋活動の記録については十 分な測定精度を有することが確認できだ4)。また，BMS に対する寝返り運動や装置への接触の影響は, 従来のポ リグラフシステムと比較して同程度か，もしくは少ない ものであった25,26).

このようにBMS の基礎デー夕の結果は好ましいもの であったが, 本装置のブラキシズム評価装置としての実 用化を図るためには，さらに実際の夜間デー夕に関する 検証が必要である。そこで, 本研究では, ブラキサー群 と非ブラキサー群を対象として BMS を使用し, 自宅に おける夜間睡眠時の咀嚼筋の活動を支障なく測定できる かどうかを検証した.

\section{II. 研究方法}

\section{1. 被験者}

対象は, 北海道大学病院歯科診療センターの受診患者 から選択したブラキサー群 9 名（男性 2 名, 女性 7 名, 平均年齢36.1 16.6歳）と本学職員から選択した非ブラ キサー群 9 名（男性 3 名，女性 6 名，平均年齢 $40.9 \pm$ 13.9歳) とした。

ブラキサー群の組み入れ基準は， $\mathrm{A}$ ：これまで歯ざし り音の指摘を受けたことがあり, B : さらに下記の 2 項 目のうち 1 項目以上を認め, C : 他の疾患に起因するブ ラキシズムではないものとした.

i 、象牙質まで達する歯牙の咬耗

ii . 起床時の頢の痛みまたは疲労感

非ブラキサー群は，歯ぎしり音の指摘，起床時の頢の 痛み, 疲労感がなく, 非生理的な過度の歯牙の咬耗を認 めないものとした.

両群共通の除外基準は可綴式補綴物の使用, 矯正を含 めた歯科処置の治療中のものとした。
なお, 本研究は本学歯学研究科倫理委員会の承認を得 ており, 被験者には事前に十分な説明を行い, 研究参加 の同意を得た。また，被験者には，各自の通常の平均的 な睡眠時間を30分単位で自己申告してもらった。

\section{2. 超小型コードレス筋電図計測システム，BMS}

BMS は, 測定電極, 不関電極, 増幅アンプ,フィルター, $\mathrm{AD}$ コンバータ, $\mathrm{CPU}$, 発信器などを一体化した超小型 送信ユニット $(42.5 \mathrm{~mm} \times 37.0 \mathrm{~mm} \times 6.5 \mathrm{~mm}$, 電池装着 時 $12.1 \mathrm{~g} ）$ および受信部と CFカードインターフェース を有する小型受信ユニットからなる（図 1)。増幅アン プはゲイン 500 倍であり, 周波数特性 $10 \sim 500 \mathrm{~Hz}$, 分解 能8bit, サンプリング周波数 $1 \mathrm{kHz}$ のデジタル信号で受 信器に送信されC Fカードメモリに記録される。電極 は直径 $12 \mathrm{~mm}$ の 2 つの測定電極と 1 つの不関電極が三 角形に配置しており, 電極中心間距離は $22 \mathrm{~mm}$ である. 電極部分に専用の導電性粘着ゲルパッドを貼り，皮庯に 粘着して使用する，送信アンテナの先端には固定用のク リップが付いている．受信アンテナは受信ユニットの本 体から離れた位置に設置可能である。

\section{3. 測定方法}

測定は被験者の自宅にて 2 日間行った。被験者に対 し送信ユニットの貼付部位等の写真付きの説明書を用い て, 装置の使用方法について十分に説明を行った，装置 は被験者が自宅に持ち帰り, 説明書内のチェックシート に従って被験者自身が装置の設定を行った。

測定部位は右側咬筋部とし，電極貼付部の皮膚を十分 に清拭した後, 電極部の導電性粘着ゲルパッドにて送信 ユニットを皮虚に粘着させ,ささらに上からテープで 3 箇 所固定した. 送信アンテナの先端は頭頂部の髪にクリッ プで固定するようにした．受信アンテナは睡眠中に頭部 から50 cm 以内の距離になるように枕元に設定した。

測定開始後に, 仰臥位の状態で最大咬みしめ, 㗆下, タッピングを行ってもらった．入眠と起床の時刻の確 認には, 非利き腕の手首に装着した腕時計型の小型睡眠 センサー, アクティグラフ（A・M・I 社製）を用いた。 アクティグラフと BMS のデータの時刻を一致させるた めに BMS の測定開始時刻を記録してもらった。

2 日目の測定の際は, 被験者に送信ユニットの電池 の交換, 電極部の粘着ゲルパッドの交換を行ってもら い, 1 日目と同様の条件で測定を行った.

\section{4. データ解析}

解析は第一夜効果 ${ }^{13)}$ を排除するために，2 日目のデー 


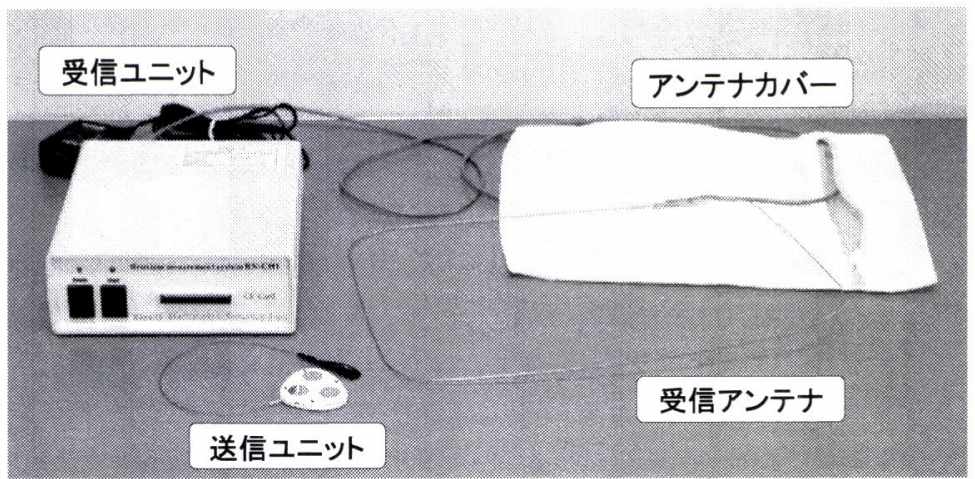

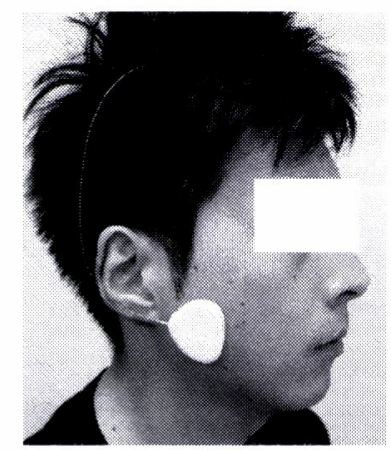

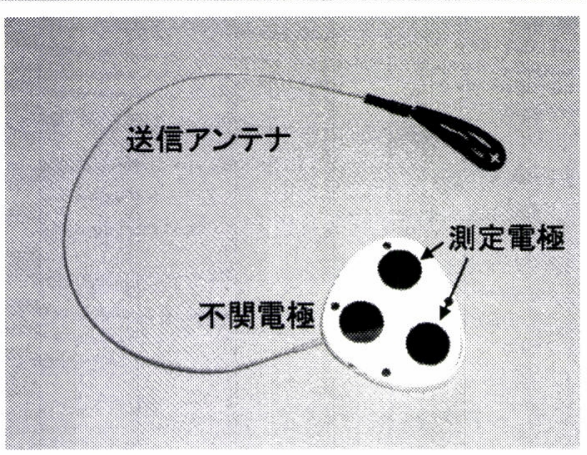

b

困 1 超小型コードレス筋電図計測システム，BMS（送信ユニット，受信ユニット） $\mathrm{a}$ ：送信ユニット装着時の様子 $\mathrm{b}$ ：送信ユニットの拡大

Fig. 1 Photos of the ultraminiature cordless electromyogram measurement system, BMS (the transmitter unit and the receiver unit).

a: A state of the transmitter unit attached to the skin surface.

b: An enlarged view of the transmitter unit.

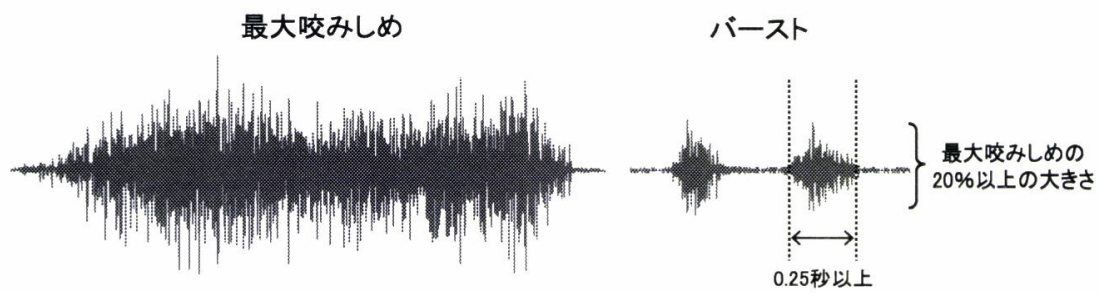

図 2 睡眠時咬筋筋電図から抽出するバーストの振幅と持続時間の閾值の設定

Fig. 2 Setting of the threshold in amplitude and duration of bursts selected from EMG data of the masseter muscle during sleep.

夕を対象として行った. BMS のデータは BMS 付属のソ フトでファイル変換した後, Chart5 (ADInstruments 社製) にて波形の解析を行った。筋電図波形は20 Hz のデジ夕 ルハイパスフィルタ処理を行い, 測定開始直後に行っ た最大咬みしめ波形の最大振幅に対する比率 (percent maximal voluntary contraction: \% MVC) が20\% MVC 以 上で 0.25 秒以上持続する筋活動をバーストとして抽出し た。(図 2)

アクティグラフのデータは，睡眠覚醒自動判別推定ソ フト $\mathrm{AW} 2(\mathrm{~A} \cdot \mathrm{M} \cdot \mathrm{I}$ 社製) にて分単位で入眠時刻と起 
表 1 両群の夜間睡眠時筋活動と睡眠時間の比較

Table 1 Comparison of EMG data during sleep and sleep time between bruxers and non-bruxers.

\begin{tabular}{|c|c|c|c|c|}
\hline & & ブラキサー群（n=9） & 非ブラキサー群（n=9） & \\
\hline \multirow[t]{2}{*}{ バースト数（回） } & total & $\begin{array}{c}269.0 \pm 309.6 \\
{[38-1050]}\end{array}$ & $\begin{array}{c}37.6 \pm 39.1 \\
{[4-127]}\end{array}$ & NS (Mw) \\
\hline & 1 時間当たり & $\begin{array}{l}42.1 \pm 40.1 \\
{[4.5-131.1]}\end{array}$ & $\begin{array}{c}6.7 \pm 6.1 \\
{[0.8-18.1]}\end{array}$ & $p<0.05(W t)$ \\
\hline \multirow[t]{2}{*}{ バースト時間（秒） } & total & $\begin{array}{l}321.4 \pm 320.0 \\
{[82.7-1142.0]}\end{array}$ & $\begin{array}{c}83.7 \pm 64.6 \\
{[18.2-210.6]}\end{array}$ & $\mathrm{NS}(\mathrm{Mw})$ \\
\hline & 1 時間当たり & $\begin{array}{l}49.8 \pm 39.4 \\
{[9.7-142.6]}\end{array}$ & $\begin{array}{l}15.6 \pm 12.5 \\
{[2.7-37.2]}\end{array}$ & $p<0.05(W t)$ \\
\hline \multirow[t]{2}{*}{ バースト積分值（mb•s） } & total & $\begin{array}{c}9.5 \pm 8.2 \\
{[1.1-29.4]}\end{array}$ & $\begin{array}{l}3.2 \pm 2.1 \\
{[0.5-5.7]}\end{array}$ & $\mathrm{NS}(\mathrm{Wt})$ \\
\hline & 1 時間当たり & $\begin{array}{c}1.5 \pm 1.1 \\
{[0.1-3.7]}\end{array}$ & $\begin{array}{l}0.6 \pm 0.5 \\
{[0.1-1.4]}\end{array}$ & $p<0.05(W t)$ \\
\hline バーストRMS 值 $(\%)^{*}$ & & {$\left[\begin{array}{c}55.7 \pm 51.4 \\
{[25.5-190.2]}\end{array}\right.$} & $\begin{array}{c}28.6 \pm 8.9 \\
{[18.2-41.7]}\end{array}$ & NS (Mw) \\
\hline バースト持続時間（秒） & & $\begin{array}{c}1.5 \pm 0.6 \\
{[0.6-2.4]}\end{array}$ & $\begin{array}{l}3.0 \pm 1.6 \\
{[1.6-5.7]}\end{array}$ & $\mathrm{p}<0.05(\mathrm{Mw})$ \\
\hline 測定睡眠時間（時間） & & $\left.\begin{array}{l}6.4 \pm 1.4 \\
{[4.3-8.5]}\end{array}\right]$ NS & 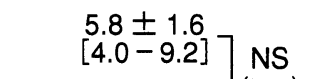 & $N S(S t)$ \\
\hline 通常の睡眠時間（時間） & & $\begin{array}{c}6.7 \pm 1.2] \text { (Ws) } \\
{[4-8]}\end{array}$ & $\begin{array}{c}6.1 \pm 0.9](W s) \\
{[5-8]}\end{array}$ & $\mathrm{NS}(\mathrm{Mw})$ \\
\hline
\end{tabular}

平均土標準偏差, [ ] : 最小值一最大值

NS : 有意差なし, Mw : Mann-Whitney's U test, Wt : Welch's t-test, St : Student's t-test, Ws : Wilcoxon signedranks test, RMS : Root Mean Square

*最大咬みしめに対する比率

床時刻を判定し,その間の時間を睡眠時間とした。また， 夜間に就寝場所から離れることがあった場合には，その 時刻を分単位で測定チェックシート内の記入欄に記録し てもらった. デー夕解析時には, 就寝場所から離れたと 申告された時間帯を含む領域のアクティグラフのデータ を確認し，アクティグラフで覚醒と判定された部分の時 間帯を分単位で筋電図デー夕の解析対象から除外した。

解析項目は, バースト数, バースト時間, バースト積 分值，各々の睡眠時間全体での合計と睡眠 1 時間当たり の值, バースト毎の持続時間と root mean square（RMS） 值の平均値である.

統計解析はエクセルアドインソフト Statcel2（オーエ ムエス出版）を用い，解析対象項目の正規性やデー夕間 の対応の有無などの条件に合わせて，マン・ホイットニ 検定, ウェルチの $\mathrm{t}$ 検定, スチューデントの $\mathrm{t}$ 検定, ウィ ルコクソン符号付き順位和検定の何れかを行った．有意 水準は $5 \%$ とした。

\section{III. 結 果}

1. すべての被験者で, 自宅での装置の設定, 操作が
可能であり，電池の交換と粘着ゲルパッドの交換によ り，2 日目の測定も可能であったままた，夜間睡眠時に 送信ユニットがはずれることはなかった。アアクティグラ フによる睡眠時間の測定結果は最短が 4.0 時間, 最長が 9.2 時間であり，睡眠時間が長い場合でも BMS のデータの 記録は可能であった。なお，被験者に申告してもらった 通常の睡眠時間と測定日の睡眠時間との間には有意差は なかった.(表 1)

2.すべての被験者の筋電図データで, 基線の安定性や 信号対雑音比 (signal to noise ratio, S/N 比)に問題はなく, 入眠前に行った最大咬みしめ, 嬩下, タッピング時の波 形や，睡眠中では，持続時間の短い phasic バーストが 約 $1 \mathrm{~Hz}$ の頻度で連続してみられる rhythmic masticatory muscle activity（RMMA）や持続時間が長い tonic バース トなどの波形を十分に認識可能であった（図 3，4）。た だし，頻度は少ないものの一部で，通信エラーと考えら れるスパイク状の形態の信号が認められた（図 4). そ れらの信号は振幅が大きいものの持続時間は短く, 直線 的であり，通常の筋活動波形とは明らかに形態が異なっ ていたため他のバーストとの識別, 除去は可能であった. 

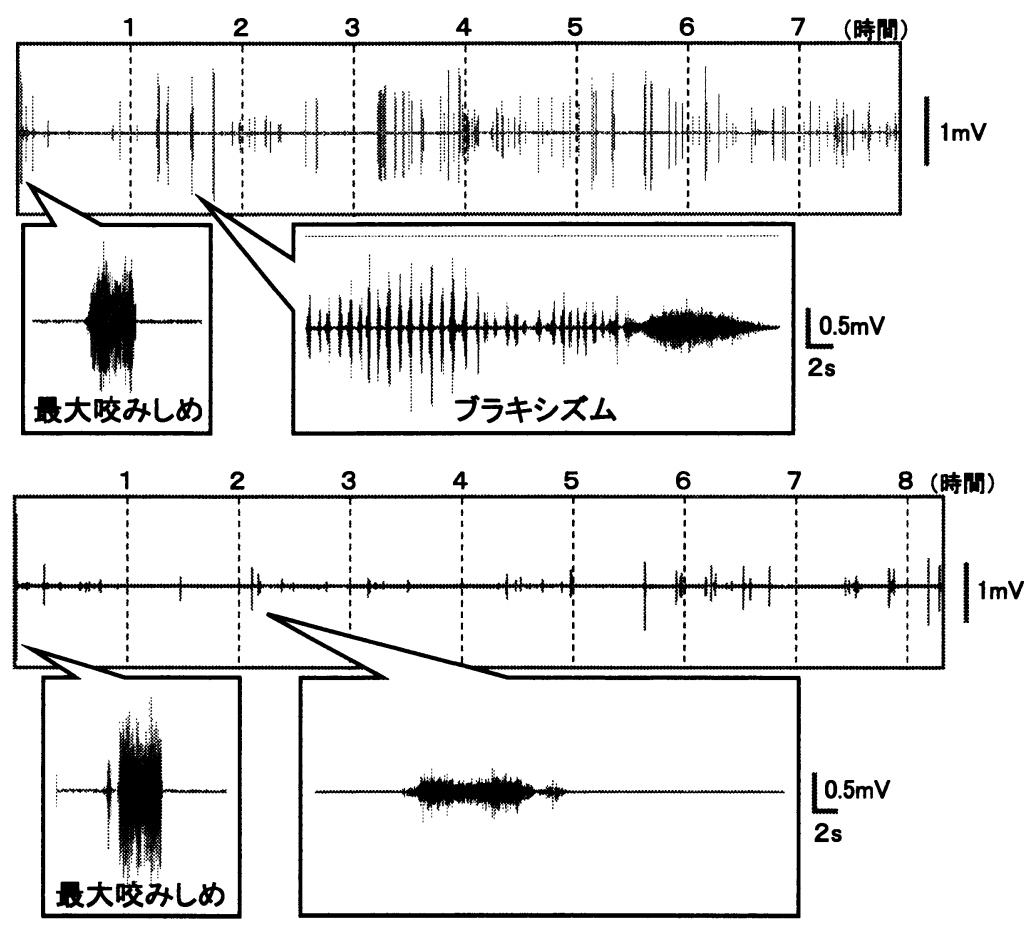

図 3 両群の夜間筋電図の例

睡眠時間全体の筋電図と睡眠前の最大咬みしめ, 睡眠時筋活動の拡大図（上：ブラキサー,ブラキ シズムと思われる phasic バーストからなる RMMA 波形と持続時間の長い tonic バーストが観察さ れる。下：非ブラキサー)

Fig. 3 Examples of EMG data for bruxers and non-bruxers obtained during sleep.

EMG data in the whole sleep period and enlarged figures of maximum voluntary clenching before sleep and muscle activities during sleep. (Upper figure: bruxer, Wave patterns of rhythmic masticatory muscle activity (RMMA) consisting of consecutive phasic bursts and a tonic burst were observed and considered as bruxism. Lower figure: non-bruxer)

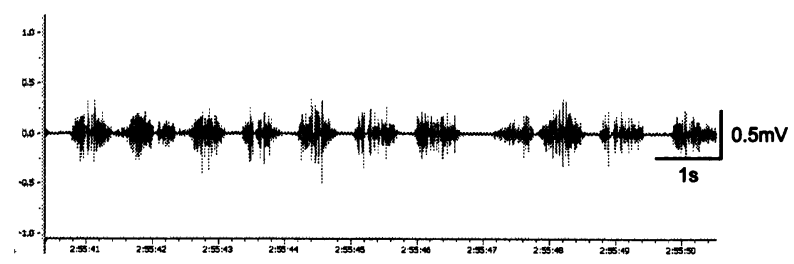

図 4 睡眠時筋電図波形の例

上：ブラキシズムと思われる RMMA 波形.下： 通信エラーと考えられるスパイク状のノイズ波 形 (矢印)

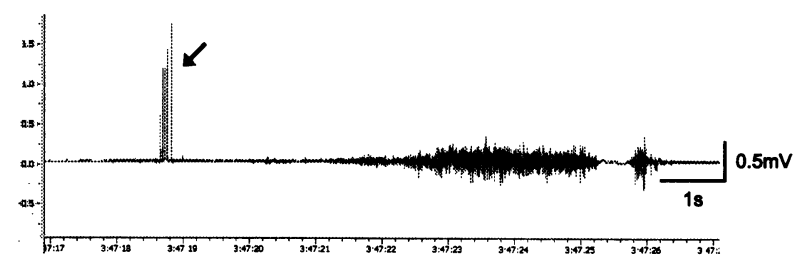

Fig. 4 Examples of EMG data during sleep. Upper figure: Wave pattern of RMMA that were thought to be bruxism. Lower figure: Artifact signals of a linear spike shape that were thought to be communication errors (arrow). 
3.ブラキサー群と非ブラキサー群の比較では, 睡眠 1 時間あたりのバースト数，バースト時間，バースト積分 值において，ブラキサー群は非ブラキサー群と比較して 有意に大きな值を示し，それぞれ前者は後者の6.3倍, 3.2 倍, 2.5倍であった。バースト毎の持続時間の平均値は, ブラキサー群は非ブラキサー群と比較して有意に小さな 值を示した。バースト RMS 值, 睡眠時間については両 群間で有意差は認められなかった。（表 1)

\section{N. 考 察}

\section{BMSについて}

本研究で，BMS は被験者自身での装置の設定により 自宅における 2 日間の夜間睡眠時の測定が可能であり, しかも測定日に通常に比べての明らかな睡眠時間の低下 が示されなかったことから，その操作性，簡便性，装置 装着による違和感についてはBMS の夜間睡眠時の咬筋 筋活動測定への実用化に際し，大きな問題にはならない ことが示唆された。

測定データについては，これまでの我々のBMSに関 する覚醒時の測定精度検証でタッピング, 最大かみしめ, ガム咀嚼を記録したところ, BMS は従来型のポリグラ フシステムと同様の明瞭な筋活動を記録できることは確 認できていた ${ }^{24)}$.また, 測定可能な送信ユニットー受信 ユニット間距離については，家電製品稼動下での通常の 室内において送受信間距離 $100 \mathrm{~cm}$ 以内ではノイズの混 入のない筋電図波形が得られていた ${ }^{24)}$ 。今回, 実際の自 宅における睡眠時の測定においても咬筋筋活動を明確に 認識できたことから, 後述するいくつかの注意点を考慮 に入れておけば，BMS は睡眠時の臨床的な咬筋筋活動 モニターとして十分実用可能な装置と考えられた。

SB 診断において現時点でのゴールドスタンダードと されている PSG-AV では, 筋電図以外にも脳波や心電図, 眼電図，呼吸モニ夕など，多くの生体現象を同時に測定 できる，それに対し，BMS は筋電図のみの測定である ことから睡眠状態の把握が困難である。 また，映像情 報がないため，䜩下や他の生理的な顎顔面の動きに伴う 筋活動と SB との判別が困難な点がある.このうち, 睡 眠状態に関する欠点を補うために本研究では，小型無拘 束のアクティグラフを併用することとし，それにより入 眠，起床の時刻の判定を行った，アクティグラフは，細 かい睡眠ステージ分類まではできないものの, 睡眠・覚 醒判定では健常者に対して睡眠ポリグラフと88 90\%の 相関があるとされる ${ }^{27)}$. SB 測定の目的により，すなわち， $\mathrm{SB}$ と睡眠段階との関連や病理的メカニズムの解明など,
研究目的の測定, あるいは臨床用の測定でも, 他の睡 眠障害疾患の検査も必要な場合には，精度の高い睡眠ス テージ判定が必要であろう。しかし，SBの強さ，時間 を把握し，その顎口腔系への臨床的な影響を明らかにす るという臨床的な診断・治療目的のためには，被験者の 負担軽減を優先し，計測項目を絞り，体に装着する装置 もなるべく少なくした方が望ましいという考え方も有り 得ると思われる。そのような考えに基づいた使用目的で は，BMS を用いた測定は，その特徴を発揮できるもの と考える．SB の評価においてどのレベルまでの睡眠解 析が必要かということは，今後さらに議論されるべきだ と考えている.

他の顎顔面の動きに伴う筋活動については，今回は， ビデオ撮影を行っていないため,それらの筋活動が,デー 夕に混入した可能性は否定できない。これまでの SB 測 定におけるバーストの解析では，ある闎值以下の小さ な波形を解析対象から外すことで，讌下やその他の生 理的な筋活動の波形を除外する試みが行われてきてお り，10４0\% MVCまでさまざまな閾值が設定されてき $た^{8,12,15,28,29)}$. 今回の結果のバースト数について過去の 研究と比較すると, 1 時間あたりの平均はブラキサー 群42.1回, 非ブラキサー群6.7回であり, 過去の PSG-AV を用いた Lavigne $ら^{8)}$ のブラキサー群36.1回, 非ブラキ サー群6.2回や, PSG を用いた Van Der Zaag らの研究 のブラキサー群41.7回, 非ブラキサー群11.6回という報 告の值と比較的近い值を示していた。 また，ブラキサー の診断基準の一つとされる筋電図測定でのカットオフ 值， 1 時間あたり 25 回 $^{8)}$ という基準を両群の平均值は満 たしていた。これらの知見から，今回 $20 \%$ MVC 以上と いう閥值によりバーストを抽出したことで SB 以外の顎 顔面の動きに伴う筋活動の除外が比較的妥当に行われ た可能性が考えられる，しかしながら，本装置での最適 なバースト閾值の設定については，夜間睡眠時における PSG-AV との比較実験データを基に, 今後さらに検討し ていく必要があると考えている。 また，バースト閥值の 設定だけで，SB 以外の顎顔面の動きに伴う筋活動の除 外を完全に行うことは難しいため，BMS を用いた筋電 図モニターだけによる評価では，その他の筋活動がデー 夕に混入する可能性がある事を考虑して，デー夕の解釈 を行うことが必要である，それらの筋活動の除外が必須 である場合には，被験者の負担を優先するのではなく， 測定の目的に沿った測定システムを選択する必要がある と考えられる。 


\section{2. 研究方法について}

これまでのブラキサーを対象とした研究においてブラ キサーの組み入れ基準は様々である．American Academy of Sleep Medicine（AASM）では，2005年に International Classification of Sleep Disorders を改訂し，第 2 版を作成 した ${ }^{311}$ 。そこでは「Sleep related bruxism」の診断基準と して，A：患者によるブラキシズムの報告や自覚，B： 次の 3 項目のうち 1 つ以上 ; i 。異常な咬耗, ii . 起床 時の咀嚼筋不快感, 疲労感, 疼痛あるいは開口障害, iii. 咬筋の肥大， C：ブラキシズムの筋活動が他の疾患で説 明できないこと，が挙げられている。本研究では，この 基準を参考としたが, 咬筋の肥大は基準の設定が難しく， 今回のBの項目の中には入れなかった.

過去の睡眠に関する研究では，実験室に宿泊した場 合のデー夕は自宅でのデータと異なるといういわゆる 実験室効果が指摘されている。特に，実験第 1 夜のデー 夕にその効果が大きいという第 1 夜効果が報告されてい る ${ }^{13)}$. 今回は被験者の自宅による測定ではあるが，第 1 夜効果の影響を排除するために，2 日目のデー夕を解析 の対象とした。

夜間睡眠時の測定では，体動によるいわゆるモーショ ンアーチファクトの影響を受ける可能性が考えられる. モーションアーチファクトは電極から増幅アンプまでの コードや電極の動きに伴うノイズ波形で，その周波数は 10 $50 \mathrm{~Hz}$ といわれている32).そのため，低周波成分を 除去する必要があり，ハイパスフィルターが使用され ることが多いが，カットオフ值を低い設定に抑えられた 方が，より原波形に近い筋活動デー夕の解析ができると いうメリットがある。これまでの覚醒時の測定データで は, BMS は, 電極一增幅アンプが一体構造となっており， ケーブルモーションアーチファクトによるノイズの混入 は比較的少ない25). 本研究では，ハイパスフィルターの カットオフ值として $20 \mathrm{~Hz}$ を適用したが，基線の摇れは なく安定していたことから，BMSでは，夜間睡眠時の 測定においてもカットオフ值を高く設定する必要性は少 ないものと考えられた。

\section{3.スパイク状のノイズについて}

今回の夜間睡眠時の測定で，通信エラーと考えられ るスパイク状のノイズが部分的にみられることがあっ た。これまでの体動や，装置への接触の影響に関する 研究において, 頻度は少ないが, 同様の高振幅のスパイ ク状のノイズが観察されていた ${ }^{25,26)}$ 。これらのノイズは その形状から，体動や装置への接触による一般的なモー ションアーチファクトではなく，受信している電波の強
さが大きく変動することによる通信エラーが原因と考 えられた，電波の強さが変動する原因としては，屋内の 測定環境では反射波などの複数の電波の干渉がおこる可 能性や，アンテナが体動時に動いた場合，アンテナの周 りの物体の誘電率が変化し，アンテナ感度が変動するた め，受信した電波の強さが変動する可能性などが考えら れた。しかし，これらのスパイク状のノイズは，明らか に筋活動とは波形パターンが異なるので，ノイズの除去 は可能であると考えていた，今回の夜間睡眠時の測定に おいても同様のスパイク状のノイズが部分的にみられた が，頻度が少なく，波形の観察によりデー夕解析時に除 去が可能であった，無線テレメータシステムではこれら の通信エラーの発現を完全に防止することは難しいと考 えられるが，通信エラーの発現を減らすように今後さら に検討して行きたいと考えている。

携帯電話，無線 LAN な゙による外来ノイズについて は，それらの機器の周波数が BMS の周波数と近似して いないため, 測定デー夕に混入して影響する可能性は少 ないと考えている．実際，過去の覚醒時における実験 ${ }^{24)}$ では，BMS 送信ユニットから50 cm の距離で携帯電話 を使用した状況でも，それに起因したアーチファクト信 号は検出されなかった。ただし，すべての機器について 検証している訳ではないため，基本的に，BMS の受信 ユニットは携带電話，無線 LAN など電磁波を発生する 機器から，可能な範囲で離して使用した方が無難と思わ れる．外来ノイズの影響の有無に関しても，今後さらに 検討して行きたい。

\section{4.ブラキサー群のバースト值について}

今回の結果で, 1 時間あたりのバースト数, バース 卜時間，バースト積分値において，ブラキサー群は非ブ ラキサー群と比較して有意に大きな值を示したことは， BMS の夜間使用の有用性を示す上で好ましい結果であ る. 前述のように 1 時間あたりのバースト数について, ブラキサー群と非ブラキサー群における結果が，過去の 研究結果と類似の傾向を示したことからもBMS の測定 による睡眠時の筋活動の認識が適切である可能性が示唆 された。なお，バースト毎の持続時間は，非ブラキサー 群と比較し，ブラキサー群で有意に小さな值を示した が，これはブラキサー群では典型的なブラキシズムの筋 活動波形である RMMA の割合が高かったためと考えら れた。

以上, 本研究結果より, BMS は被験者自身での装置 の設定による自宅での夜間睡眠時の測定が可能であり， そのデータは，通信エラー信号の稀な混入に注意を払 
えば，睡眠時咬筋筋活動のバーストを明確に認識できる ものであったことから睡眠時の臨床的な咬筋筋活動モニ ターとして十分実用可能な装置と考えられた.さらには, ブラキサー群と非ブラキサー群の筋活動の差を認識でき ることが示されたことから，筋活動単独でブラキシズム を評価する際の特性を理解した上でデータの解釈を行う ことにより, 睡眠時ブラキシズムの評価装置としての実 用化の可能性が示された.

今後はさらに症例数, 測定日数を増やし, ブラキシズ ムバースト識別の最適閥值検討，ブラキシズムイベント としての評価法等の解析項目についての検討, さらに自 動解析ソフトの導入について検討し, SB 評価法として の夜間睡眠時咬筋筋活動測定への本装置の本格導入を進 めて行く予定である.

\section{V. 結 論}

超小型コードレス筋電図計測システム, BMS をブラ キサー群と非ブラキサー群を対象とした自宅における 夜間睡眠時の咬筋筋活動の測定に応用したところ，睡 眠時の筋活動波形の認識，解析が可能なことが示され， BMS は睡眠時の臨床的な咬筋筋活動モニターとして実 用可能な装置と考えられた。

\section{V. 謝 辞}

本研究に関して, BMS の開発に携わり, 多くの御助 言を頂きました原田証英氏，黒澤圭司氏ほか原田電子工 業株式会社の皆様, また, 親身な御助言と御支援を頂き ました本学高齢者歯科学教室, 井上農夫男教授に深く感 謝致します。

\section{VI. 文 献}

1) Manfredini, D., Cantini, E., Romagnoli, M. et al.: Prevalence of bruxism in patients with different research diagnostic criteria for temporomandibular disorders (RDC/TMD) diagnoses, Cranio, 21: 279-285, 2003.

2 ) Kampe, T., Tagdae, T., Bader, G. et al.: Reported symptoms and clinical findings in a group of subjects with longstanding bruxing behaviour, J Oral Rehabil, 24: 581-587, 1997.

3 ) Drum, W.: A new concept of periodontal diseases, J Periodontol, 46: 504-510, 1975.

4 ) Pintado, M.R., Anderson, G.C., Delong, R. et al.:
Variation in tooth wear in young adults over a two-year period, J Prosthet Dent, 77: 313-320, 1997.

5 ) Cohen, S., Blanco, L., Berman, L.: Vertical root fractures: clinical and radiographic diagnosis, Am Dent Assoc, 134: 434-441, 2003.

6 ）友永章雄, 池田雅彦, 加藤 熙ほか: Sleep bruxism が修復物脱落に及ぼす影響, 補綴誌, $49: 221-230$, 2005.

7 ) Okeson, J.P., Phillips, B.A., Berry, D.T.R. et al.: Nocturnal bruxing events in healthy geriatric subjects, J Oral Rehabil, 17: 411-418, 1990.

8 ) Lavigne, G.J., Rompre, P.H., Montplaisir, J.Y.: Sleep bruxism: validity of clinical research diagnostic criteria in a controlled polysomnographic study, J Dent Res, 75 546-552, 1996.

9) 大倉一夫：マルチテレメータシステムを用いた 睡眠時ブラキシズムの測定と解析, 補綴誌, 41 : 292-301, 1997.

10) Okkerse, W., Brebels, A., De Deyn, P.P. et al.: Influence of a bite-plane according to Jeanmonod, on bruxism activity during sleep, J Oral Rehabil, 29: 980-985, 2002.

11) Dube, C., Rompre, P.H., Manzini, C. et al.: Quantitative polygraphic controlled study on efficacy and safety of oral splint devices in tooth-grinding subjects, J Dent Res, 83: 398-403, 2004.

12) van der Zaag, J., Lobbezoo, F., Wicks, D.J. et al.: Controlled assessment of the efficacy of occlusal stabilization splints on sleep bruxism, J Orofac Pain, 19: 151-158, 2005.

13) Edinger, D.J., Fins, A.I., Sullivan, R.J. et al.: Sleep in the laboratory and sleep at home: comparison of older insomniacs and normal sleepers, Sleep, 20: 1119-1126, 1997.

14) Rivera-morales, W.C. and McCall Jr, W.D.: Reliability of a portable electromyographic unit to measure bruxism, $\mathrm{J}$ Prosthet Dent, 73: 184-189, 1995.

15) Ikeda, T., Nishigawa, K., Kondo, K. et al.: Criteria for the detection of sleep-associated bruxism in humans, $\mathrm{J}$ Orofac Pain, 10: 270-282, 1996.

16) Gallo, L.M., Lavigne, G., Rompre, P. et al.: Reliability of scoring EMG orofacial events: polysomnography compared with ambulatory recordings, J Sleep Res, 6: 259-263, 1997.

17) Bowley, J.F. and Marx, D.B.: Masticatory muscle activity assesssment and reliability of portable electromyographic 
instrument, J Prosthet Dent, 85: 252-260, 2001.

18) Harada, T., Ichiki, Y., Tsukiyama, Y. et al.: The effect of oral splint devices on sleep bruxism: a 6-week observation with an ambulatory electromyographic recording device, J Oral Rehabil, 33: 482-488, 2006.

19) Solberg, W.K., Clark, G.T., Rugh, J.D.: Nocturnal electromyographic evaluation of bruxism patients undergoing short term splint therapy, J Oral Rehabil, 2: 215-223, 1975.

20）市来利香, 築山能大, 古谷野潔 : 携帯型筋電図測定 システムの開発と睡眠時咬筋筋活動の日間変動の観 察への応用，顎機能誌，6:67-77, 1999.

21）坂上竜資, 加藤 熙, 土田泰之ほか：ブラキシ ズム自動解析システムの開発, 日歯保存誌, 45 ： 349-355, 2002.

22) Haketa, T., Baba, K., Akishige, S. et al.: Utility and validity of a new EMG-based bruxism detection system, Int J Prosthodont, 16: 422-428, 2003.

23) Minakuchi, H. and Clark, G.T.: The sensitivity and specificity of a miniature bruxism detection device, $\mathrm{J}$ Dent Res, 83 (Special issue A) CDROM of Abstracts, 2460, 2003.

24) Yamaguchi, T., Mikami, S., Okada, K.: Validity of a newly developed ultraminiature cordless EMG measurement system, Oral Surg Oral Med Oral Pathol Oral Radiol Endod, 104: e22-27, 2007.

25) Mikami, S., Yamaguchi, T., Okada, K. et al.: Influence of motion and posture of the head on data obtained using the newly developed ultraminiature cordless bruxism measurement system, J Prosthodont Res, 53: 22-27, 2009.

26）三上紗季，山口泰彦，岡田和樹：超小型コードレ ス筋電図計測システムの開発一装置への接触の影 響一, 日本スポーツ歯科医学会学術大会プログラム 抄録集19回：65，2008.

27) Ancoli-Israel, S., Cole, R., Alessi, C. et al.: The role of actigraphy in the study of sleep and circadian rhythms, Sleep, 26: 342-392, 2003.

28) Okeson, J.P., Phillips, B.A., Berry, D.T. et al.: Nocturnal bruxing events: a report of normative data and cardiovascular response, J Oral Rehabil, 21: 623-630, 1994.

29) Hiyama, S., Ono, T., Ishiwata, Y. et al.: First night effect of an interocclusal appliance on nocturnal masticatory muscle activity, J Oral Rehabil, 30: 139-145, 2003.

30) Van Der Zaag, J., Lobbezoo, F., Visscher, C.M. et al.: Time-variant nature of sleep bruxism outcome variables using ambulatory polysomnography: implications for recognition and therapy evaluation, J Oral Rehabil, 35: 577-584, 2008.

31) AASM. Sleep related bruxism: The international classification of sleep disorders. (Diagnostic and coding manual) 2nd edition ed, Westchester, American Academy of Sleep Medicine, 189-192, 2005.

32) Clancy, E.A., Morin, E.L., Merletti, R.: Sampling, noisereduction and amplitude estimation issues in surface electromyography, J Electromyogr Kinesiol, 12: 1-16, 2002. 